\title{
Pengaruh Kecerdasan Emosional terhadap Burnout pada Perawat dengan Coronavirus Anxiety sebagai Variabel Mediator
}

\author{
ABDUL KARIM \& HERISON PANDAPOTAN PURBA* \\ Departemen Psikologi Industri dan Organisasi, Fakultas Psikologi Universitas Airlangga
}

\begin{abstract}
ABSTRAK
Penelitian ini bertujuan untuk mengetahui pengaruh kecerdasan emosional terhadap burnout pada perawat di Surabaya dengan coronavirus anxiety sebagai variabel mediator. Profesi keperawatan lebih banyak mengalami tekanan kerja dan burnout dibandingkan dengan profesi kesehatan lainnya. Selain itu, perawat juga dapat mengalami kecemasan selama masa pandemi COVID-19. Mengoptimalkan kecerdasan emosional merupakan faktor kunci yang dapat mengurangi tingkat kecemasan dan burnout. Partisipan dalam penelitian ini merupakan perawat di Kota Surabaya dengan total sebanyak 77 perawat. Alat ukur yang digunakan yaitu Maslach Burnout Inventory, Assessing Emotions Scale, dan Coronavirus Anxiety Scale. Analisis data menggunakan uji mediasi dengan metode PROCESS by Andrew $F$. Hayes. Hasil analisis data menunjukkan nilai pengaruh secara tidak langsung sebesar $-0,1229$. Hasil tersebut menunjukan adanya peran mediasi dari coronavirus anxiety yang secara tidak langsung mengendalikan pengaruh kecerdasan emosional terhadap burnout dan peran mediasi bersifat parsial.
\end{abstract}

Kata kunci: burnout, coronavirus anxiety, kecerdasan emosional, perawat

\begin{abstract}
This study aims to determine the effect of emotional intelligence on burnout on nurses in Surabaya with coronavirus anxiety as a mediator variable. The nursing profession experiences more work pressure and burnout than other health professions. In addition, nurses can experience anxiety during the COVID19 pandemic. Optimizing emotional intelligence is a key factor in reducing anxiety and burnout. Participants in this study were nurses in the city of Surabaya with a total of 77 nurses. The measuring instruments used were the Maslach Burnout Inventory, the Assessing Emotions Scale, and the Coronavirus Anxiety Scale. Data analysis used mediation test with PROCESS method by Andrew F. Hayes. The results of data analysis show the value of the indirect effect of -0.1229 . These results indicate a mediating role for coronavirus anxiety which indirectly controls the effect of emotional intelligence on burnout and the role of mediation is partial.
\end{abstract}

Keywords: burnout, coronavirus anxiety, emotional intelligence, nurse

Buletin Penelitian Psikologi dan Kesehatan Mental (BRPKM), tahun 2021, Vol. 1(1), 448-459

*Alamat korespondensi: Fakultas Psikologi Universitas Airlangga, Kampus B Universitas Airlangga Jalan Airlangga 4-6 Surabaya 60286. Surel: herison.purba@psikologi.unair.ac.id

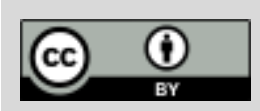

Naskah ini merupakan naskah dengan akses terbuka dibawah ketentuan the Creative Common Attribution License (CC-BY-4.0) (http://creativecommons.org/licenses/by/4.0), sehingga penggunaan, distribusi, reproduksi dalam media apapun atas artikel ini tidak dibatasi, selama sumber aslinya disitir dengan baik. 


\section{PEN D A H U L U A N}

Burnout menjadi masalah utama pada sektor pekerjaan tenaga kesehatan, terutama selama masa pandemi COVID-19 (Sultana dkk., 2020). Burnout dapat dialami oleh berbagai profesi, namun seringkali terjadi pada profesi yang berhubungan langsung dengan seseorang, salah satunya perawat (Bakker dkk., 2002). Perawat merupakan profesi yang lebih banyak mengalami tekanan kerja dan burnout dibandingkan dengan individu yang bekerja di pusat layanan kesehatan lainnya (Mousavi dkk., 2017; Odonkor \& Frimpong, 2020). Hal tersebut disebabkan karena perawat berpeluang lebih banyak kontak dekat dengan pasien, berisiko lebih besar terinfeksi, serta beban fisik dan mental yang meningkat dua kali lipat (Guixia \& Hui, 2020). Burnout dapat terjadi dalam jangka waktu yang lebih lama atau lebih pendek, tergantung pada situasi yang dialami dan kapasitas dalam beradaptasi dengan situasi tersebut (Landa \& López-Zafra, 2010).

Tenaga kesehatan yang menangani pasien COVID-19 mengalami tingkat burnout yang beragam dan berpotensi dapat meningkat (CNN Indonesia, 2020). Penelitian dari Fakultas Kedokteran Universitas Indonesia (FKUI) menunjukkan bahwa tenaga kesehatan di Indonesia mengalami burnout tingkat sedang dan berat sebesar 83\% selama pandemi COVID-19 yang dapat dilihat dari tiap dimensi burnout, kelelahan emosional sebesar $41 \%$, depersonalisasi sebesar 22\%, dan penuruanan pencapaian diri sebesar 52\% (Humas FKUI, 2020). Maslach dkk. (2019) menyebutkan bahwa burnout akan berdampak terhadap kualitas perawatan yang buruk, tingkat kepuasan pasien yang rendah, dan masalah keselamatan pasien. Burnout juga berdampak terhadap pengabaian kepedulian perawat terhadap pasien, sehingga mengarahkan pasien, keluarga dan masyarakat percaya bahwa tidak ada kepedulian tentang kesejahteraan emosional dan fisik pasien. Dampak lainnya yang disebabkan oleh burnout yaitu perawat mengundurkan diri, produktivitas yang menurun, sehingga berisiko kerugian pada organisasi (Maslach dkk., 2019). Selain itu, juga dapat mengalami disfungsi mental seperti, seperti kecemasan, depresi, self-esteem yang menurun, dan gejala emosional lainnya (Maslach \& Leiter, 2017).

Stresor kerja dapat diketahui dari kondisi kerja perawat yang dikenal sebagai karakteristik pekerjaan yang terdiri dari job demands (lembur kerja, beban kerja, lingkungan kerja, tuntutan komunikasi, dan emotional labour) dan job resources (gaji, keamanan kerja, task freedom dan dukungan rekan kerja), dan dikenal sebagai anteseden dalam kesehatan psikologis dan mental (Nel dkk., 2013). Tuntutan kerja yang tinggi jika tidak diimbangi dengan sumber daya yang memadai, maka individu akan mempersepsikan lingkungan kerja lebih negatif dan akhirnya dapat menyebabkan burnout (Fletcher, 2003 dalam Nel dkk., 2013).

Keperawatan pada dasarnya adalah suatu profesi yang mengalami tingkat stres yang tinggi, sebagian karena sifat dari tugas yang spesifik dan pasien yang mereka asuh (Landa \& López-Zafra, 2010). Pekerjaan yang berkaitan dengan pelayanan, khususnya pelayanan kesehatan sangat berkaitan erat dengan emotional labour yang menjadi fundamental dalam kinerja perawat. Hochschild (1983) mendefinisikan emotional labour sebagai usaha menekan atau meredam suatu perasaan atau emosi untuk menciptakan suasana yang penuh perhatian dan aman bagi klien. Suatu pekerjaan dapat dikategorikan termasuk dalam emotional labour umumnya memiliki tiga karakteristik, yaitu kontak secara intensif dengan orang lain, kebutuhan untuk mengekspresikan kondisi emosional yang positif pada orang lain, dan sekumpulan aturan baik secara tersirat maupun tersurat mengenai tipe ekspresi emosi yang dianggap layak dan tidak layak (Hochschild, 2003).

Burnout berasal dari interaksi sosial antara yang menawarkan layanan dan yang menerimanya, pengelolaan emosi yang tepat dalam interaksi tersebut merupakan faktor kunci yang dapat menjelaskan mengapa beberapa individu lebih tahan terhadap timbulnya burnout daripada yang lain (Landa \& López-Zafra, 2010). Mengoptimalkan kecerdasan emosional merupakan faktor kunci yang dapat 
mengurangi burnout di tempat kerja (Gong dkk., 2019). Hasil penelitian Heikkila (2018) menyatakan bahwa kecerdasan emosional dapat menurunkan tingkat burnout sebesar $20 \%$ pada perawat, dengan prosentase penurunan pada setiap dimensi burnout sebagai berikut: kelelahan emosional sebesar 8,4\%, depersonalisasi sebesar 10,1\%, dan penurunan pencapaian diri berkurang sebesar 11,9\%.

Selain kecerdasan emosional, tingkat kecemasan juga dapat memperediksi tingkat burnout. Hasil penelitian Wan dkk. (2020) menunjukkan bahwa kecemasan yang dialami oleh perawat COVID-19 berhubungan positif dengan burnout, dengan kata lain semakin tinggi tingkat kecemasan, maka semakin tinggi tingkat kelelahan emosional, depersonalisasi, dan rendahnya pencapaian diri. Tingkat kecemasan yang tinggi, menunjukkan adanya suatu kondisi menegangkan yang dapat mengembangkan atau memperburuk gejala burnout dan tekanan psikologis (Giusti dkk., 2020). Kecemasan merupakan keadaan gelisah atau ketakutan yang dihasilkan akibat dari antisipasi terhadap peristiwa atau situasi yang nyata atau dianggap mengancam (Spielberger, 2010 dalam Labrague \& Santos, 2020).

Kecemasan terkait dengan pandemi COVID-19 sangat umum terjadi pada pekerjaan perawat, sumber utama kecemasan pada perawat yaitu takut akan tertular dan menularkan kepada orang lain (Labrague \& Santos, 2020). Perawat yang menangani pasien COVID-19 mengalami tingkat kecemasan yang tinggi (Wan dkk., 2020). Hasil penelitian Labrague \& Santos (2020) juga menunjukkan bahwa sejumlah 123 $(37,8 \%)$ perawat mengalami kecemasan disfungsional. Kecemasan disfungsional mengacu pada keadaan kecemasan yang tidak proporsional, yang didefinisikan sebagai ketakutan yang terus-menerus atau tidak terkendali yang mengganggu kehidupan sehari-hari dan menyebabkan gangguan pada perilaku dan kesejahteraan psikologis (Lee, 2020).

Hasil penelitian Fiorilli dkk. (2020) menunjukkan bahwa secara konseptual kecemasan memiliki peran yang dapat memediasi hubungan antara kecerdasan emosional dengan burnout. Kecerdasan emosional merupakan salah satu faktor yang dapat menurunkan kecemasan, yang secara tidak langsung juga dapat meredam gejala burnout. Berdasarkan uraian tersebut, maka penting untuk mengetahui bagaimana pengaruh kecerdasan emosional terhadap burnout yang dimediasi oleh coronavirus anxiety pada perawat.

\section{Burnout}

Istilah "burnout" pertama kali muncul dalam literatur medis pada tahun 1974 yang diperkenalkan oleh Freudenberger untuk menggambarkan kelelahan karena adanya tuntutan yang berlebihan pada pekerjaan. Burnout merupakan suatu kegagalan atau kelelahan setelah menggunakan kekuatan atau sumber daya energi secara berlebihan (Freudenberger, 1974). Maslach dkk. (2001) mendefinikan burnout sebagai respon dari stresor emosional dan interpersonal yang kronis secara berkepanjangan dengan ditandai adanya kelelahan emosional (emotional exhausted), depersonalisasi (depersonalization), dan penurunan pencapaian diri (reduce personal accomplishment).

Poin penting dari burnout yaitu munculnya kelelahan emosional yang semakin meningkat. Kelelahan pada dasarnya merepresentasikan stress individu dengan ditandai kehilangan energi dan kekurangan sumber daya emosional. Sinisme atau depersonalisasi merepresentasikan konteks interpersonal yang mengacu pada tanggapan yang negatif, sinis, atau terpisah dengan berbagai aspek pekerjaan. Penurunan pencapaian diri merepresentasikan evaluasi diri yang mengacu pada perasaan tidak kompeten, kurangnya prestasi dan produktivitas di tempat kerja (Maslach dkk., 2001). 


\section{Kecerdasan Emosional}

Kecerdasan emosional merupakan konsep yang berawal dari kecerdasan sosial, yang dikemukakan oleh Thorndike pada tahun 1920. Thorndike mendefinisikan kecerdasan sosial sebagai kemampuan untuk memahami diri sendiri dan orang lain, motif dan perilaku, serta bertindak secara optimal berdasarkan informasi tersebut (dalam Salovey \& Mayer, 1990). Istilah kecerdasan emosional pertama kali dikemukakan oleh Salovey \& Mayer (1990), yang merupakan bagian dari kecerdasan sosial yang melibatkan kemampuan adaptif untuk mengamati perasaan dan emosi diri sendiri serta orang lain, membedakan di antara keduanya, dan menggunakan informasi tersebut sebagai panduan dalam berpikir dan bertindak.

Kecerdasan emosional yang dikemukakan oleh Salovey \& Mayer (1990) masih menggunakan satu dimensi, dimana hanya ada satu faktor yang mewakili aspek-aspek kecerdasan emosional itu sendiri. Namun, Ciarrochi dkk. (2001) dalam penelitiannya mengemukakan bahwa satu faktor tersebut masih dapat dipecah lagi menjadi empat dimensi, yakni persepsi terhadap emosi (perception of emotions), mengelola emosi diri sendiri (managing emotions in the self), mengelola emosi orang lain (managing others' emotions), dan memanfaatkan emosi (utilizing emotions).

\section{Coronavirus Anxiety}

Freud merupakan tokoh pertama yang mencoba menjelaskan makna kecemasan dalam konteks teori psikologi (Spielberger, 1966). Kecemasan merupakan keadaan gelisah atau ketakutan yang dihasilkan akibat dari antisipasi terhadap peristiwa atau situasi yang nyata atau dianggap mengancam (Spielberger, 2010 dalam Labrague \& Santos, 2020). Spielberger (1966) menyebutkan bahwa kecemasan terdiri dari dua aspek yang berbeda, yaitu trait anxiety dan state anxiety. Trait anxiety diartikan sebagai karakteristik individu yang stabil atau kepribadian yang relatif permanen dan sejauh mana ia memandang situasi stres sebagai ancaman, yaitu, kecenderungan seseorang terhadap kecemasan. Di sisi lain, state anxiety adalah reaksi individu terhadap suatu keadaan sementara atau yang terus berubah dari waktu ke waktu yang dinilai mengancam (Spielberger, 1966).

Kecemasan secara umum terjadi di antara tenaga kesehatan yang terlibat langsung dalam menangani pasien yang terinfeksi selama pandemi (Labrague \& Santos, 2020). Coronavirus Anxiety didefinisikan sebagai ketakutan yang terus-menerus atau tidak terkendali yang mengganggu kehidupan sehari-hari dalam menanggapi pandemi COVID-19 yang ditandai dengan gejala fisiologis antara lain pusing, gangguan tidur, kelumpuhan di luar kendali (tonic immobility), kehilangan nafsu makan dan mual atau sakit perut (Lee, 2020).

Dengan demikian, berikut ini merupakan hipotesis dalam penelitian ini:

Ha1: Ada pengaruh kecerdasan emosional terhadap burnout dengan coronavirus anxiety secara signifikan pada perawat di Surabaya.

Ha2: Ada pengaruh kecerdasan emosional terhadap coronavirus anxiety secara signifikan pada perawat di Surabaya.

Ha3: Ada pengaruh coronavirus anxiety terhadap burnout secara signifikan pada perawat di Surabaya.

Ha4: Ada pengaruh kecerdasan emosional terhadap burnout dengan coronavirus anxiety sebagai variabel mediator secara signifikan pada perawat di Surabaya.

Ho1: Tidak ada pengaruh kecerdasan emosional terhadap burnout secara signifikan pada perawat di Surabaya. 
Ho2: Tidak ada pengaruh kecerdasan emosional terhadap coronavirus anxiety secara signifikan pada perawat di Surabaya.

Ho3: Tidak ada pengaruh coronavirus anxiety terhadap burnout secara signifikan pada perawat di Surabaya.

Ho4: Tidak ada pengaruh kecerdasan emosional terhadap burnout dengan coronavirus anxiety sebagai variabel mediator secara signifikan pada perawat di Surabaya.

\section{Desain Penelitian}

\section{E T O D E}

Penelitian ini menggunakan pendekatan kuantitatif dengan tipe explanatory research (Neuman, 2014). Tipe penelitian tersebut dipilih karena sesuai dengan tujuan dari penelitian ini, yaitu untuk mengetahui pengaruh kecerdasan emosional terhadap burnout pada pada perawat dengan coronavirus sebagai variabel mediator.

\section{Partisipan}

Populasi yang digunakan dalam penelitian ini adalah perawat di Surabaya. Teknik sampling yang digunakan dalam penelitian ini adalah non-probability sampling dengan metode purposive sampling (Neuman, 2014). Dalam menentukan sampel, penulis mengacu pada pedoman Tabachnick \& Fidell (2013 dalam Pallant, 2016) untuk menentukan jumlah minimal sampel dengan rumusan $\mathrm{N}>50+8 \mathrm{~m}$. Berdasarkan perhitungan menggunakan rumus tersebut, maka jumlah minimal sampel yang dibutuhkan dalam penelitian ini sejumlah 66 partisipan. Teknik pengambilan data yang digunakan dalam penelitian ini yaitu metode survei atau kuesioner (Neuman, 2014). Setelah menyebarkan kuesioner, penulis mendapatkan partisipan sejumlah 77 perawat di Surabaya.

\section{Pengukuran}

Instrumen yang digunakan untuk mengukur kecerdasan emosional adalah Assessing Emotions Scale (AES) yang dikembangkan oleh Schutte dkk. (1998) dengan sejumlah 33 aitem yang terdiri dari 30 aitem favorable dan 3 aitem unfavorable. Alat ukur ini menggunakan skala Likert dengan 5 pilihan jawaban (1="sangat tidak setuju", $5=$ "sangat setuju"), dengan reliabilitas yang cukup baik $(\alpha=.862)$. Instrumen yang digunakan untuk mengukur burnout adalah Maslach Burnout Inventory (MBI) yang dikembangkan oleh Maslach \& Jackson (1981), dengan sejumlah 22 aitem yang terdiri dari 14 aitem favorable dan 8 aitem unfavorable. Alat ukur ini menggunakan skala Likert dengan 6 pilihan jawaban $(0=$ "tidak pernah, $6=$ "setiap hari dirasakan"), dengan reliabilitas yang cukup baik $(\alpha=.715)$. Instrumen yang digunakan untuk mengukur coronavirus anxiety adalah Coronavirus Anxiety Scale (CAS) yang dikembangkan oleh Lee (2020), dengan sejumlah 5 aitem favorable. Alat ukur ini menggunakan skala Likert dengan 4 pilihan jawaban ( $0=$ "tidak sama sekali", 4="hampir setiap hari"), dengan reliabilitas yang cukup baik $(\alpha=.746)$.

\section{Analisis Data}

Sebelum melakukan analisis data regresi, penulis melakukan uji asumsi terlebih dahulu, yaitu uji normalitas, uji linieritas, dan uji homokedastisitas dengan menggunakan bantuan program IBM SPSS 22.0 for Windows. Kemudian untuk mengetahui peran mediasi coronavirus anxiety antara kecerdasan emosional dengan burnout menggunakan PROCESS v3.5 by Andrew F. Hayes pada IBM SPSS 22.0 for Windows. 


\section{HAS I L P E N EL I T I A N}

\section{Uji Deskriptif}

Analisis deskriptif dilakukan untuk mengetahui karakteristik umum yang terdiri dari rentang populasi (range), nilai minimum, nilai maksimum, rata-rata (mean), standar deviasi, skewness dan kurtosis.

Berdasarkan hasil data analisis deskriptif dapat diketahui bahwa jumlah data yang diperoleh penulis sebanyak 77 subjek. Variabel burnout menunjukkan nilai minimum 17, nilai maksimum 73, range sebesar 56, dan nilai rata-rata sebesar 47,31 atau perolehan rata-rata skor sebesar $(47,31 / 22)=2,15$ yang dapat diartikan bahwa rata-rata subjek mengalami sekali dalam sebulan merasa burnout. Variabel coronavirus anxiety menunjukkan nilai minimum 2, nilai maksimum 14, range sebesar 12 dan nilai ratarata sebesar 7,52 atau perolehan rata-rata skor sebesar $(7,52 / 5)=1,5$ yang dapat diartikan bahwa ratarata subjek mengalami kecemasan lebih dari 1-2 kali dalam 2 minggu terakhir. Variabel kecerdasan emosional menunjukkan nilai minimum 99, nilai maksimum 152, range sebesar 53 dan nilai rata-rata sebesar 128,06 atau perolehan rata-rata skor sebesar $(128,06 / 33)=3,8$ yang dapat diartikan bahwa rata-rata subjek memiliki kecerdasan emosional yang sedang.

\section{Uji Asumsi}

Selanjutnya penulis melakukan uji asumsi, dengan analisis uji normalitas dan uji linieritas terlebih dahulu agar dapat menentukan teknik statistik yang digunakan untuk menguji hipotesis penelitian.

Berdasarkan hasil uji normalitas dapat diketahui bahwa nilai signifikansi burnout sebesar 0,063, coronavirus anxiety sebesar 0,053, dan kecerdasan emosional 0,200. Ketiga variabel tersebut berdistribusi normal, karena memiliki signifikansi lebih dari 0,05.

Kemudian, penulis melakukan uji linieritas yang dapat diketahui hasilnya bahwa nilai signifikansi hubungan antara kecerdasan emosional terhadap burnout sebesar 0,002, kecerdasan emosional terhadap coronavirus anxiety sebesar 0,003 dan coronavirus anxiety terhadap burnout sebesar 0,000. Sehingga, dapat disimpulkan bahwa hubungan antara kedua variabel tersebut dapat dikatakan linear, karena nilai signifikansinya kurang dari 0,05.

\section{Uji Mediasi}

Sebelum melakukan uji mediasi, penulis melakukan uji regresi terlebih dahulu agar memenuhi syarat untuk dilakukan uji medasi. Menurut Baron \& Kenny (1986) terdapat tiga syarat yang harus dipenuhi untuk membuktikan peran variabel mediasi. Pertama, variabel independen harus mempengaruhi mediator; kedua, variabel independen harus terbukti mempengaruhi variabel dependen; dan ketiga, mediator harus mempengaruhi variabel dependen.

Berdasarkan hasil uji regresi kecerdasan emosional berpengaruh signifikan terhadap burnout dengan signifikansi sebesar 0,001, kecerdasan emosional berpengaruh signifikan terhadap coronavirus anxiety dengan signifikansi sebesar 0,001, dan coronavirus anxiety berpengaruh signifikan terhadap burnout dengan signifikansi sebesar 0,005. Hasil tersebut dapat disimpulkan bahwa pengaruh antar variabel telah memenuhi tiga syarat, karena nilai signifikansi menunjukkan kurang dari 0,05. Sehingga dapat membuktikan peran variabel mediasi, yang kemudian akan dilanjutkan dengan uji mediasi.

Model mediasi sederhana dengan satu variabel mediator dapat ditunjukkan melalui pengaruh variabel $\mathrm{X}$ dapat dibagi menjadi dua, yaitu pengaruh langsung (jalur $\mathrm{c}^{\prime}$ ) dan tidak langsung (jalur $\mathrm{a}^{*} \mathrm{~b}$ ), yaitu pengaruh X terhadap Y melalui M. Sedangkan, (jalur c) merupakan pengaruh total X terhadap Y secara langsung tanpa mengendalikan variabel M terhadap Y (Preacher \& Hayes, 2008). 
Berdasarkan hasil uji mediasi pengaruh langsung (jalur c') menunjukkan koefisiensi sebesar -0,2579, pengaruh (jalur a) menunjukkan nilai koefisiensi sebesar -0,0756, dan pengaruh (jalur b) menunjukkan koefisiensi sebesar 1,6260. Sehingga, dapat diketahui bahwa peran mediasi atau pengaruh tidak langsung (jalur $\mathrm{a}^{*} \mathrm{~b}$ ) menunjukkan koefisiensi sebesar -0,1229. Sedangkan pengaruh total (jalur c) dapat dihitung dengan menjumlahkan nilai koefisiensi (jalur $c^{\prime}+\left(a^{*} b\right)$ ) yang akan menghasilkan koefiensi sebesar -0,3808. Data di atas menunjukkan bahwa seluruh jalur variabel menunjukkan taraf $\mathrm{p}<0,05$ yang berarti dapat dikatakan signifikan.

Adanya efek mediasi atau tidak, dapat diketahui melalui pengaruh tidak langsung (jalur a*b) sebesar 0,1229 dengan interval kepercayaan (Confidence Interval / CI) 95\% dari hasil bootstrap berkisar antara BootLLCI (lower level for CI) sebesar -0,2467 sampai BootULCI (upper level for CI) sebesar -0,0328. Jika rentang BootLLCI dan BootULCI itu tidak mencakup nilai nol (0), maka dapat disimpulkan bahwa terdapat efek mediasi coronavirus anxiety yang signifikan antara pengaruh kecerdasan emosional terhadap burnout.

\section{I S K U S I}

Penelitian ini bertujuan untuk mengetauhi apakah kecerdasan emosional memiliki pengaruh terhadap burnout dengan coronavirus anxiety sebagai variabel mediator. Secara keseluruhan, hasil dari penelitian ini mendukung hipotesis korelasi dan mediasi. Berdasarkan hasil analisis yang telah dilakukan dapat disimpulkan bahwa terdapat adanya pengaruh (jalur a) kecerdasan emosional terhadap burnout tanpa melibatkan variabel mediasi coronavirus anxiety, yang berarti Ho1 ditolak dan Ha1 diterima. Hasil analisis regresi dengan menggunakan metode PROCESS by Andrew F. Hayes menunjukkan nilai signifikansi di bawah 0,05 dan nilai koefisiensi sebesar -0,3808. Sehingga, dapat diartikan bahwa kecerdasan emosional memiliki pengaruh negatif terhadap burnout secara signifikan, yaitu apabila individu dengan kecerdasan emosional yang tinggi, maka dapat menurunkan tingkat burnout.

Hasil dari penelitian ini sejalan dengan penelitian yang telah dilakukan oleh Heikkila (2018) menyatakan bahwa kecerdasan emosional dapat menurunkan tingkat burnout. Perawat yang tidak cerdas secara emosional, maka tidak akan mampu mengatasi tuntutan pekerjaan dan akan lebih rentan mengalami burnout, serta keterlibatan yang rendah, sehingga pada akhirnya akan memengaruhi kesejahteraan mereka di tempat kerja (Nel dkk., 2013). Sebaliknya, jika perawat menguasai kecerdasan emosional, maka rekan kerja, pasien, dan keluarga akan merasa diperhatikan, serta menimbulkan kepuasan (White \& Grason, 2019). Perawat yang cerdas secara emosional akan lebih mampu memahami dan mengelola emosi diri sendiri dan orang lain, sehingga perawat dapat menghadapi lingkungan kerja yang kompleks lebih mudah (tuntutan pekerjaan yang tinggi, sumber daya pekerjaan yang rendah) dan menjadi lebih engaged dan burnout lebih rendah, yang pada akhirnya akan menghasilkan kesejahteraan kerja yang lebih baik. Burnout merupakan konsekuensi dari emosi yang tidak teruji, maka dari itu kecerdasan emosional dapat menjadi vital bagi perawat agar lebih terlibat dalam pekerjaan mereka (Nel dkk., 2013).

Berdasarkan hasil analisis yang telah dilakukan dapat disimpulkan bahwa terdapat adanya pengaruh kecerdasan emosional terhadap coronavirus anxiety, yang berarti Ho2 ditolak dan Ha2 diterima. Hasil analisis regresi dengan menggunakan metode PROCESS by Andrew F. Hayes menunjukkan nilai signifikansi di bawah 0,05 dan nilai koefisiensi sebesar -0,0756. Sehingga, dapat diartikan bahwa kecerdasan emosional memiliki pengaruh negatif terhadap coronavirus anxiety secara signifikan, yaitu apabila individu dengan kecerdasan emosional yang tinggi, maka dapat menurunkan tingkat coronavirus anxiety. 
Hasil dari penelitian ini sejalan dengan beberapa hasil penelitian sebelumnya yang menunjukkan bahwa kecerdasan emosional secara negatif berkorelasi dengan tingkat kecemasan (Fernández-Berrocal dkk., 2006; Liu \& Ren, 2016; Zarei dkk., 2019). Fernández-Berrocal dkk. (2006) menyatakan bahwa kecerdasan emosional menunjukkan hubungan yang kuat dan signifikan dengan self-esteem, depresi, dan kecemasan. Zarei dkk. (2019) menyatakan bahwa kecerdasan emosional yang tinggi dapat menurunkan tingkat kecemasan. Sebaliknya, jika individu dengan kecerdasan emosional yang rendah, maka akan melaporkan kecemasan yang tinggi (Liu \& Ren, 2016). Individu dengan kecerdasan emosional yang tinggi dapat mengidentifikasi, mengekspresikan, dan memahami emosi dan perasaan serta meregulasi emosi negatif (kecemasan) (Ouyang et al. 2015 dalam Liu \& Ren, 2016). Individu yang mampu membedakan dengan jelas antara perasaan dan meregulasi keadaan emosional menunjukkan tingkat kecemasan lebih rendah (Fernández-Berrocal dkk., 2006). Liu \& Ren (2016) menyatakan bahwa kecerdasan emosional dapat berfungsi sebagai faktor pencegah dari kecemasan.

Berdasarkan hasil analisis yang telah dilakukan dapat disimpulkan bahwa terdapat adanya pengaruh coronavirus anxiety terhadap burnout, yang berarti Ho3 ditolak dan Ha3 diterima. Hasil analisis regresi dengan menggunakan metode PROCESS v3.5 by Andrew F. Hayes menunjukkan nilai signifikansi di bawah 0,05 dan nilai koefisiensi sebesar 1,6260. Sehingga, dapat diartikan bahwa coronavirus anxiety memiliki pengaruh positif terhadap burnout secara signifikan, yaitu apabila individu mengalami coronavirus anxiety yang tinggi, maka dapat meningkatkan tingkat burnout.

Hasil dari penelitian ini sejalan dengan penelitian yang dilakukan oleh Wan dkk. (2020) yang menunjukkan bahwa kecemasan yang dialami oleh perawat COVID-19 berhubungan positif dengan burnout, dengan kata lain semakin tinggi tingkat kecemasan, maka semakin tinggi tingkat kelelahan emosional, depersonalisasi, dan rendahnya pencapaian diri. Lee (2020) menyatakan bahwa coronavirus anxiety berhubungan secara signifikan dengan gangguan klinis seperti psikologis, interpersonal, dan perilaku. Kecemasan yang terus-menerus dialami oleh perawat dapat membahayakan keseimbangan fisik dan mental (Mousavi dkk., 2017) yang berhubungan dengan penurunan fungsi tubuh, mekanisme koping negatif (seperti mengkonsumsi alkohol atau obat-obatan), stres dan depresi, dan peningkatan keinginan untuk bunuh diri (Lee, Jobe, dkk., 2020). Tingkat kecemasan yang tinggi menunjukkan adanya suatu kondisi menegangkan yang dapat mengembangkan atau memperburuk gejala burnout dan tekanan psikologis (Giusti dkk., 2020).

Berdasarkan hasil analisis yang telah dilakukan dapat disimpulkan bahwa terdapat adanya peran mediasi parsial dari coronavirus anxiety yang secara tidak langsung mengendalikan pengaruh kecerdasan emosional terhadap burnout, yang berarti Ho4 ditolak dan Ha4 diterima. Hasil analisis regresi dengan menggunakan metode PROCESS v3.5 by Andrew F. Hayes menunjukkan nilai pengaruh secara tidak langsung sebesar -0,1229. Sehingga, dapat diartikan bahwa kecerdasan emosional memiliki pengaruh secara langsung maupun tidak langsung terhadap burnout yang signifikan melalui coronavirus anxiety sebagai variabel mediator. Apabila individu dengan kecerdasan emosional yang tinggi, maka dapat menurunkan tingkat coronavirus anxiety, yang kemudian juga dapat menurunkan tingkat burnout.

Hasil dari penelitian ini sejalan dengan penelitian yang dilakukan oleh Fiorilli dkk. (2020) yang menyatakan bahwa kecemasan memiliki peran yang dapat memediasi hubungan antara kecerdasan emosional dengan burnout. Individu dengan tingkat kecerdasan emosional yang tinggi cenderung tidak mengalami kecemasan, yang kemudian dapat mengurangi risiko burnout (Fiorilli dkk., 2020). Fernández-Berrocal dkk. (2006) menyatakan bahwa individu yang mampu membedakan dengan jelas antara perasaan dan meregulasi keadaan emosional menunjukkan tingkat kecemasan dan depresi yang lebih rendah. Keadaan cemas akan terinfeksi atau menginfeksi orang lain yang dialami oleh perawat 
dapat menimbulkan burnout. Koutsimani dkk. (2019) menyatakan bahwa apabila individu rentan mengalami kecemasan yang tinggi, maka dapat meningkatkan tingkat burnout. Kecerdasan emosional merupakan salah satu faktor yang dapat menurunkan kecemasan, yang secara tidak langsung juga dapat meredam gejala burnout.

\section{S I M P U L A N}

Berdasarkan hasil penelitian yang telah dilakukan, maka dapat disimpulkan bahwa terdapat adanya peran mediasi parsial dari coronavirus anxiety yang secara tidak langsung mengendalikan pengaruh kecerdasan emosional terhadap burnout. Sehingga, dapat diartikan bahwa kecerdasan emosional memiliki pengaruh secara langsung maupun tidak langsung terhadap burnout yang signifikan melalui coronavirus anxiety sebagai variabel mediator. Apabila individu dengan kecerdasan emosional yang tinggi, maka dapat menurunkan tingkat coronavirus anxiety, yang kemudian juga dapat menurunkan tingkat burnout.

Saran bagi penelitian selanjutnya diharapkan dapat menentukan jumlah jenis kelamin laki-laki dan perempuan yang lebih seimbang. dengan adanya jumlah yang seimbang antara laki-laki dan perempuan mendapatkan hasil yang representatif pada kategori jenis kelamin. Selain itu, penelitian selanjutnya dapat menggunakan alat ukur, seperti Mayer-Salovey-Caruso Emotional Intelligence Test (MSCEIT) yang merupakan performance test untuk menguji kemampuan kecerdasan emosional individu dengan cara memecahkan masalah tentang emosi atau permasalahan yang membutuhkan penggunaan emosi (Mayer dkk., 2002).

Selanjutnya, terdapat beberapa saran bagi pihak rumah sakit, antara lain; mulai proses rekruitmen, pimpinan pihak rumah sakit harus memperhatikan kualitas pelamar, seperti memiliki sikap postif dan rasa peduli yang tulus; peningkatan kinerja organisasi, pimpinan pihak rumah sakit harus fokus untuk memberikan dukungan psikologis kepada perawat dan menyusun program pendidikan dan pelatihan yang kompeten, seperti patient relationship management dan keterampilan sosial dalam strategi koping, sehingga memungkinkan perawat untuk melakukan perawatan terhadap pasien dengan kualitas terbaik (Huang dkk., 2020; White \& Grason, 2019); hingga strategi pencegahan, pihak rumah sakit perlu mempertimbangkan dengan hati-hati beban kerja dan jam kerja perawat, serta menyusun rencana kerja yang sesuai, yang mengarahkan pada kinerja pekerjaan yang baik dan dapat menurunkan tingkat burnout. Memberikan fasilitas layanan psikolog untuk perawat agar dapat menceritakan dan melepaskan stres dan ketegangan yang dialami terkait dengan pekerjaan mereka (Nel dkk., 2013). Selain itu, mengenali sumber kecemasan memungkinkan para pemimpin tenaga kesehatan dan organisasi dapat mengembangkan pendekatan untuk mengatasi permasalahan tersebut dan memberikan dukungan khusus untuk para tenaga kesehatan (Shanafelt dkk., 2020), sehingga dapat melakukan tindakan preventif atau pencegahan yang tepat. Cara terbaik untuk memahami apa yang paling dikhawatirkan yaitu dengan bertanya langsung pada perawat.

\section{U C A P A N T E R I MAKASIH}

Penulis mengucapkan terima kasih kepada dosen pembimbing dan segenap sivitas akademik Fakultas Psikologi Universitas Airlangga yang telah membantu tercapainya penelitian ini, serta seluruh partisipan yang telah bersedia meluangkan waktunya dan bersedia terlibat dalam penelitian ini, sehingga dapat terselesaikan dengan baik. 


\section{DEKLARASI POTENSI TERJADINYA KONFLIK KEPENTINGAN}

Abdul Karim dan Herison Pandapotan Purba tidak bekerja, menjadi konsultan, memiliki saham, atau menerima dana dari perusahaan atau organisasi manapun yang mungkin akan mengambil untung dari diterbitkannya naskah ini.

\section{PUSTAKA ACUAN}

Bakker, A. B., Demerouti, E., \& Schaufeli, W. B. (2002). Validation of the Maslach Burnout Inventory General survey: An Internet study. Anxiety, Stress and Coping, 15(3), 245-260. https://doi.org/10.1080/1061580021000020716

Baron, R. M., \& Kenny, D. A. (1986). The Moderator-Mediator Variable Distinction in Social Psychological Research. Conceptual, Strategic, and Statistical Considerations. Journal of Personality and Social Psychology, 51(6), 1173-1182. https://doi.org/10.1037/0022-3514.51.6.1173

Ciarrochi, J., Chan, A. Y. C., \& Bajgar, J. (2001). Measuring emotional intelligence in adolescents. Personality and Individual Differences, 31(7), 1105-1119. https://doi.org/10.1016/S01918869(00)00207-5

CNN Indonesia. (2020). Studi: 83 Persen Nakes Alami Burnout Sedang sampai Berat. Cnnindonesia.Com.

Fernández-Berrocal, P., Alcaide, R., Extremera, N., \& Pizarro, D. (2006). The role of emotional intelligence in anxiety and depression among adolescents. Individual Differences Research, 4(1), 16-27.

Fiorilli, C., Farina, E., Buonomo, I., Costa, S., Romano, L., Larcan, R., \& Petrides, K. V. (2020). Trait emotional intelligence and school burnout: The mediating role of resilience and academic anxiety in high school. International Journal of Environmental Research and Public Health, 17(9). https://doi.org/10.3390/ijerph17093058

Freudenberger, H. J. (1974). Staff Burn-Out. Journal of Social Issues, 30(1), 159-165.

Giusti, E. M., Pedroli, E., D’Aniello, G. E., Stramba Badiale, C., Pietrabissa, G., Manna, C., Stramba Badiale, M., Riva, G., Castelnuovo, G., \& Molinari, E. (2020). The Psychological Impact of the COVID-19 Outbreak on Health Professionals: A Cross-Sectional Study. Frontiers in Psychology, 11(July), 1-9. https://doi.org/10.3389/fpsyg.2020.01684

Gong, Z., Chen, Y., \& Wang, Y. (2019). The Influence of Emotional Intelligence on Job Burnout and Job Performance: Mediating Effect of Psychological Capital. 10(December), 1-11. https://doi.org/10.3389/fpsyg.2019.02707

Guixia, L., \& Hui, Z. (2020). A Study on Burnout of Nurses in the Period of COVID-19. 9(3), 31-36. https://doi.org/10.11648/j.pbs.20200903.12

Heikkila, D. M. (2018). The Relationship between Certified Registered Nurse Anesthetists' Emotional Intelligence and Burnout. [Walden University]. http://search.ebscohost.com/login.aspx?direct=true\&db=c8h\&AN=136077290\&site=ehost-live

Hochschild, Arlie Russel. (1983). The Managed Heart: Commercialization of Human Feeling. University of California Press.

Hochschild, Arlie Russell. (2003). The Managed Heart: The Commercialization Human of Feeling

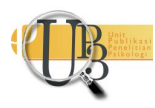




\section{Twentieth Anniversary Edition With a New Afterword.}

Huang, L., Lei, W., Xu, F., Liu, H., \& Yu, L. (2020). Emotional responses and coping strategies in nurses and nursing students during Covid-19 outbreak: A comparative study. Plos One, 15(8), e0237303. https://doi.org/10.1371/journal.pone.0237303

Humas FKUI. (2020). 83\% Tenaga Kesehatan Indonesia Mengalami Burnout Syndrome Derajat Sedang dan Berat Selama Masa Pandemi COVID-19. Fk.Ui.Ac.Id. https://fk.ui.ac.id/berita/83-tenagakesehatan-indonesia-mengalami-burnout-syndrome-derajat-sedang-dan-berat-selama-masapandemi-covid-19.html

Koutsimani, P., Montgomery, A., \& Georganta, K. (2019). The relationship between burnout, depression, and anxiety: A systematic review and meta-analysis. Frontiers in Psychology, 10, 1-19. https://doi.org/10.3389/fpsyg.2019.00284

Labrague, L. J., \& Santos, J. de los. (2020). COVID-19 anxiety among front-line nurses Predictive role of organisational support, personal resilience and social support. J Nurs Manage, 28, 1653-1661. https://doi.org/10.1111/jonm.13121

Landa, J. M. A., \& López-Zafra, E. (2010). The impact of emotional intelligence on nursing: An overview. Psychology, 1(1), 50-58. https://doi.org/10.4236/psych.2010.11008

Lee, S. A. (2020). Coronavirus Anxiety Scale: A brief mental health screener for COVID-19 related anxiety. Death Studies, 44(7), 393-401. https://doi.org/10.1080/07481187.2020.1748481

Lee, S. A., Jobe, M. C., Mathis, A. A., \& Gibbons, J. A. (2020). Incremental validity of coronaphobia: Coronavirus anxiety explains depression, generalized anxiety, and death anxiety. Journal of Anxiety Disorders, 74(July), 6-9. https://doi.org/10.1016/j.janxdis.2020.102268

Liu, M., \& Ren, S. (2016). Moderating Effect of Emotional Intelligence on the Relationship between Rumination and Anxiety. Current Psychology, 37(1), 272-279. https://doi.org/10.1007/s12144016-9510-7

Maslach, C., \& Jackson, S. E. (1981). The measurement of experienced burnout. Journal of Organizational Behavior, 2(2), 99-113. https://doi.org/10.1002/job.4030020205

Maslach, C., \& Leiter, M. P. (2017). Understanding Burnout. The Handbook of Stress and Health, 36-56. https://doi.org/10.1002/9781118993811.ch3

Maslach, C., Montgomery, A., Panagopoulou, E., Esmail, A., \& Richards, T. (2019). A Systems Approach to Burnout in Healthcare Workplaces. BMJ, 5, 1-18.

Maslach, C., Schaufeli, W. B., \& Leiter, M. P. (2001). Job Burnout. Annual Review of Psychology, 52(1), 397422.

Mayer, J. D. ., Salovey, P., \& Caruso, D. (2002). Mayer-Salovey-Caruso Emotional Intelligence Test. In Multi-Health Systems Incoporated. https://humancapitaltalent.co.za/wpcontent/uploads/2018/11/MSCEIT-Personal-SummaryReport.pdf\%0Ahttps://www.mhs.com/MHS-Talent?prodname=msceit

Mousavi, S. V., Ramezani, M., Salehi, I., Hossein Khanzadeh, A. A., \& Sheikholeslami, F. (2017). The Relationship between Burnout Dimensions and Psychological Symptoms (Depression, Anxiety and

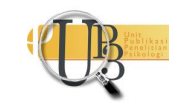


Stress) Among Nurses. Journal of Holistic Nursing and Midwifery, 27(2), 37-43. https://doi.org/10.18869/acadpub.hnmj.27.2.37

Nel, J. A., Jonker, C. S., \& Rabie, T. (2013). Emotional intelligence and wellness among employees working in the nursing environment. Journal of Psychology in Africa, 23(2), 195-203. https://doi.org/10.1080/14330237.2013.10820615

Neuman, W. L. (2014). Social research methods: qualitative and quantitative approaches. Pearson.

Odonkor, S. T., \& Frimpong, K. (2020). Burnout among Healthcare Professionals in Ghana: A Critical Assessment. BioMed Research International, 2020,1-8. https://doi.org/10.1155/2020/1614968

Pallant, J. (2016). SPSS survival manual a step by step guide to data analysis using IBM SPSS (Allen \& Uwin (eds.); 6th ed.). McGraw-Hill Education.

Preacher, K. J., \& Hayes, A. F. (2008). Asymptotic and resampling strategies for assessing and comparing indirect effects in multiple mediator models. Behavior Research Methods, 40(3), 879-891. https://doi.org/10.3758/BRM.40.3.879

Salovey, P., \& Mayer, J. D. (1990). Emotional Intelligence. Imagination, Cognition and Personality, 9(3), 185-211. https://doi.org/10.2190/DUGG-P24E-52WK-6CDG

Schutte, N. S., Malouff, J. M., Hall, L. E., Haggerty, D. J., Cooper, J. T., Golden, C. J., \& Dornheim, L. (1998). Development and validation of a measure of emotional intelligence. Personality and Individual Differences, 25(2), 167-177. https://doi.org/10.1016/S0191-8869(98)00001-4

Shanafelt, T., Ripp, J., \& Trockel, M. (2020). Understanding and Addressing Sources of Anxiety among Health Care Professionals during the COVID-19 Pandemic. JAMA - Journal of the American Medical Association, 323(21), 2133-2134. https://doi.org/10.1001/jama.2020.5893

Spielberger, C. D. (1966). Theory and Research on Anxiety. Anxiety and Behavior, 1(3), 3-20. https://doi.org/10.1016/b978-1-4832-3131-0.50006-8

Sultana, A., Sharma, R., Hossain, M., Bhattacharya, S., \& Purohit, N. (2020). Burnout among healthcare providers during COVID-19: Challenges and evidence-based interventions. Indian Journal of Medical, 1-4. https://doi.org/10.20529/IJME.2020.73.Peer

Wan, Z., Lian, M., Ma, H., Cai, Z., \& Xianyu, Y. (2020). Factors associated with burnout among Chinese nurses during COVID-19 epidemic: a cross-sectional study. Research Square, 1-19. https://doi.org/10.21203/rs.3.rs-31486/v1

White, D. E., \& Grason, S. (2019). The Importance of Emotional Intelligence in Nursing Care. Journal of Comprehensive Nursing Research and Care, 4(152), 1-3. https://doi.org/10.33790/jcnrc1100152

Zarei, F., Akbarzadeh, I., \& Khosravi, A. (2019). The Relationship between Emotional Intelligence and Stress, Anxiety, and Depression among Iranian Students. International Journal of Health Studies, 5(2), 1-5. https://doi.org/10.22100/ijhs.v5i3.668 